\title{
Australia Antigen and Hepatitis in Accra, Ghana
}

\author{
R. H. MORROW, JUN., F. T. SAI, L. F. BARKER
}

British Medical fournal, 1971, 4, 389-391

\section{Summary}

Viral hepatitis in young adults in Accra, Ghana, is associated with Australia antigen (H.A.A.). Sera from 85 patients in hospital with viral hepatitis were available for determinations of H.A.A. Of the 16 patients whose serum was obtained within the first week of symptoms, 15 were positive. The only factor related to finding H.A.A. was the time between onset of symptoms and the collection of the serum sample. Persistence of H.A.A. was associated with persistence of jaundice in men but not in women. Previous epidemiological studies in Accra found no evidence for parenteral transmission of viral hepatitis and showed a shanty-town predilection pointing to faecal-oral transmission. It thus seems that H.A.A.-associated hepatitis is transmitted in West Africa either faecal-orally or by shanty-town associated arthropods. The finding that H.A.A. hepatitis is the usual hepatitis in young adults in Accra is in accord with the high prevalence of H.A.A. elsewhere in the general population in Africa and may be related to the high rate of cirrhosis and hepatoma in Africa.

\section{Introduction}

Australia antigen (H.A.A.), originally described by Blumberg (1964) and Blumberg et al. (1965), is closely associated with long-incubation (serum or group B) hepatitis (Giles et al., 1969; Shulman et al., 1970). Though H.A.A. has been found in some cases of infectious hepatitis (Blumberg et al., 1970; Cossart and Vahrman, 1970) it has not been detected in sera in welldefined epidemics of short-incubation hepatitis in Europe and North America (Mosley et al., 1970; Del Prete et al., 1970).

In Africa, where hepatitis is common, the prevalence of H.A.A. in the general population is from 1 to $6 \%$ compared with about $0.1 \%$ in Europe and North America (Prince, 1970). In West African cities morbidity and mortality rates from viral hepatitis are particularly high among young adults (Mabayoje, 1962; Ogunlesi, 1962; Payet et al., 1962; Morrow et al., 1968). The increase of hepatitis in Accra since the second world war has accompanied the development of shanty towns with poor sanitation, accommodating the large number of young men looking for work, and where the spread of infection is attributed to gross faecal pollution (Morrow et al., 1969).

Hepatitis in Accra also displays some unusual clinical, pathological, and epidemiological features characterized by a high rate of acute hepatic coma, prolonged jaundice, and death; an unusually severe course in pregnant women; an unusually prolonged course in men; and an association with glucose 6-phosphate dehydrogenase deficiency. Liver biopsies from

Department of Tropical Public Health, Harvard School of Public Health, Boston, Massachusetts 02115, U.S.A.

R. H. MORROW, jun., M.D., M.P.H., Associate Professor

Ministry of Health, Accra, Ghana

F. T. SAI, M.D., F.R.C.P.ED., M.P.H., Director of Medical Services for Ghana

Laboratory of Viral Immunology, Division of Biological Standards, National Institutes of Health, Bethesda, Maryland, U.S.A.

L. F. BARKER, M.D., Senior Investigator

these patients show a distinctive histological pattern of a "glandular" transformation of liver cells around bile canaliculi, a high frequency of cholestasis, and a paucity of acidophilic bodies (Morrow et al., 1968, 1969).

In this report we give the results of H.A.A. studies on patients in hospital with viral hepatitis in Accra, Ghana.

\section{Population and Procedures}

Between 1 November 1962 and 1 November 1963136 patients were admitted to Korle Bu Hospital with a clinical diagnosis of viral hepatitis subsequently confirmed by liver biopsy or necropsy (Morrow et al., 1968). Sera were available from 85 of the 136 patients, and serial specimens from 64 of the 85 . The age and sex distribution of the 85 patients is shown in Table I. Serum was obtained from patients on the day of or day after admission and at weekly or two-weekly intervals thereafter,

TABLE I-Age and Sex Distribution of the Hepatitis Patients from Whom Sera were Available

\begin{tabular}{|c|c|c|c|c|c|}
\hline \multicolumn{3}{|c|}{ Age } & Females & Males & Total \\
\hline \multirow[t]{2}{*}{$\begin{array}{c}0-4 \\
5-14 \\
15-24 \\
25-44 \\
45-64 \\
65+\end{array}$} & $\begin{array}{l}\ldots \\
\because . \\
\ldots \\
\ldots\end{array}$ & $\begin{array}{l}\because \\
\because \\
\because \\
\cdots\end{array}$ & $\begin{array}{r}2 \\
4 \\
14 \\
12 \\
2 \\
1\end{array}$ & $\begin{array}{r}3 \\
1 \\
17 \\
23 \\
6 \\
0\end{array}$ & $\begin{array}{r}5 \\
5 \\
31 \\
35 \\
8 \\
1\end{array}$ \\
\hline & & & 35 & 50 & 85 \\
\hline
\end{tabular}

and was stored at $-20^{\circ} \mathrm{C}$. Sera were sent to the Division of Biologic Services, National Institutes of Health, Bethesda, U.S.A., in 1964, and were stored there at $-20^{\circ} \mathrm{C}$.

H.A.A. was determined by Ouchterlony immunodiffusion technique (Blumberg et al., 1965) and by microtitre complement fixation method (Shulman and Barker, 1969; Barker et al., 1970). In the microtitre complement fixation method for detecting H.A.A. sera to be tested are first heated for 30 minutes at $56^{\circ} \mathrm{C}$. Twofold serum dilutions, starting at 1:5, are then incubated at $4^{\circ} \mathrm{C}$ for 16 to 18 hours in the presence of complement, 1.7 to 2 units, and antibody against H.A.A., 2 to 4 units. Fixation of complement is assessed by adding sheep red blood cells sensitized with haemolysin and incubating the mixture for 30 minutes at $35^{\circ} \mathrm{C}$. Controls consisting of test sera without antibody against H.A.A. are included to detect anticomplementary activity. Anticomplementary sera were considered negative unless they gave a positive result in agar gel diffusion.

Antibodies to H.A.A. were sought for by passive haemagglutination (Vyas and Shulman, 1970), but results were uninterpretable because of the high incidence of background agglutination of the normal unsensitized $O$ negative red blood cells.

\section{Results}

Sera from patients early in their illness were virtually all positive (Table II). The sooner a specimen was obtained the more likely it was to be positive. No other variables (age, sex, place of birth and residence, severity of disease, etc.) were important except to the extent that they affected the opportunity for early diagnosis and admission to hospital. 
Sera from a miscellaneous group of 23 adults with other illnesses, admitted to hospital at the same time, but not specifically selected as controls for the hepatitis patients, were available for H.A.A. testing. Two were positive by complement fixation, four were anticomplementary, and 17 were negative.

TABLE II-H.A.A. Related to Time after Onset of Symptoms

\begin{tabular}{cc|r|r|c|c|c}
\hline \multicolumn{2}{c|}{$\begin{array}{c}\text { Days after } \\
\text { Onset* }\end{array}$} & \multicolumn{2}{c|}{ Positive } & \multirow{2}{*}{ Negative } & Anticomplementary & \multirow{2}{*}{ Total } \\
\cline { 2 - 4 } & No. & $\%$ & & & \\
\hline $1-7$ &. & 15 & 94 & 1 & 0 & 16 \\
$8-14$ & $\because$ & 18 & 72 & 4 & 3 & 25 \\
$15-21$ & $\because$ & 7 & 54 & 4 & 2 & 7 \\
$22-29$ & $\because$ & 1 & 14 & 4 & 5 & 17 \\
$30-59$ & $\because$ & 2 & 12 & 10 & 4 & 7 \\
$60+$ &. & 1 & 14 & 4 & 14 & 85 \\
\hline & & 44 & & 27 & 2 & \\
\hline
\end{tabular}

-First available serum of patient tested.

TABLE III-Duration of Faundice Related to Persistence of H.A.A.

\begin{tabular}{|c|c|c|c|c|c|c|c|c|c|c|}
\hline \multirow{3}{*}{$\begin{array}{l}\text { Weeks after } \\
\text { Onset to } \\
\text { First } \\
\text { Negative } \\
\text { H.A.A. }\end{array}$} & \multicolumn{5}{|c|}{ Males } & \multicolumn{5}{|c|}{ Females } \\
\hline & \multicolumn{4}{|c|}{ Weeks of Jaundice } & \multirow{2}{*}{ Total } & \multicolumn{4}{|c|}{ Weeks of Jaundice } & \multirow{2}{*}{ Total } \\
\hline & $1-2$ & 3-6 & $7-11$ & $12+$ & & $1-2$ & 3-6 & $7-11$ & $12+$ & \\
\hline $\begin{array}{l}1-2 \\
3-4 \\
5-6 \\
7-11 \\
12+\end{array}$ & $\begin{array}{l}0 \\
1 \\
1 \\
0 \\
0\end{array}(1)$ & $\begin{array}{l}0 \\
6(3) \\
3 \\
2 \\
1\end{array}$ & $\begin{array}{l}2 \\
4 \\
3 \\
6(3) \\
0\end{array}$ & $\begin{array}{l}0 \\
3 \\
4(1) \\
8(4) \\
5(3)\end{array}$ & $\begin{array}{r}2 \\
14 \\
11 \\
16 \\
6\end{array}$ & $\begin{array}{l}0 \\
1 \\
1 \\
2 \\
0\end{array}$ & $\begin{array}{l}2 \\
1 \\
7(1) \\
3(1) \\
0\end{array}$ & $\begin{array}{l}2 \\
2(1) \\
8(1) \\
3 \\
1\end{array}$ & $\begin{array}{l}0 \\
0 \\
1 \\
1 \\
0\end{array}(1)$ & $\begin{array}{r}4 \\
4 \\
17 \\
9 \\
1\end{array}$ \\
\hline & 2 & 12 & 15 & 20 & $49 *$ & 4 & 13 & 16 & 2 & 35 \\
\hline
\end{tabular}

* One patient died while deeply jaundiced at 12 days and is not included.

Note: Numbers in parentheses indicate sera that were still positive for H.A.A. in patients who continued to be jaundiced thereafter, but in whom further sera were not available. No sera negative for H.A.A. were obtained from these patients. For purposes of $\chi^{2}$ calculation it was assumed 0.05 by $\chi^{3}$ for linear trend for males.

Table III relates the duration of jaundice to the persistence of H.A.A. In males H.A.A. persisted parallel with the duration of jaundice, but no such relationship was apparent in females. However, duration of jaundice in females was usually much shorter than in males. Only 2 out of 35 females studied as against 20 out of 49 males remained jaundiced after three months.

H.A.A. persisted in the males whose jaundice was markedly prolonged; the last sera available in the four men still jaundiced after 8,11, 12, and 15 months were positive. Two men with chronic hepatitis who died after jaundice lasting respectively six and six and a.half months were also consistently positive for H.A.A.

\section{Discussion}

Our interpretation of the results is that hepatitis in adults in Accra is associated with H.A.A. Despite the high prevalence of H.A.A. in Africa we had not expected to find such a high rate of H.A.A. in our patients because the epidemiological pattern did not suggest parenteral transmission (Morrow et al., 1968, 1969).

In our study $29.2 \%$ of patients had received some kind of parenteral injection in the six months before their illness, but so had $31.4 \%$ of age- and sex-matched controls admitted to hospital for acute illness other than hepatitis (Morrow et al., 1969). Though a few patients received injections or scarifications from traditional practitioners who do not generally use sterile instruments, most had received their treatment from Government outpatient clinics. Though a covert mechanism of parenteral transmission, such as that described in Sweden (Ringentz and Zetterberg, 1967), cannot be ruled out, a more probable hypothesis is that H.A.A.-associated hepatitis can be effectively spread by the faecal-oral route.

Serum from patients with long-incubation hepatitis can be infectious orally as well as parenterally (Krugman et al., 1967), and recently H.A.A. was identified in the faeces of H.A.A. hepatitis patients (Grob and Jemelka, 1971). A few reports provide evidence for oral transmission of long-incubation hepatitis (Mirick and Shank, 1959; Krugman and Giles, 1970), but transmission by the faecal-oral route has been considered inefficient and uncommon. A puzzling aspect of our study was that few patients had had known contact with hepatitis, and none of their relatives developed symptomatic hepatitis (Morrow et al., 1969). An alternative hypothesis to faecal-oral spread to explain the timing, geographical distribution, and lack of intrafamilial spread in Accra is that transmission occurred via arthropods that favour shanty towns-namely, Aedes aegypti, soft ticks (Ornithodoros moubata), Congo floor maggots (Auchmeromyia luteola), bed bugs, or fleas.

A potential link in understanding the relationship of hepatitis to cirrhosis and hepatoma is the finding that H.A.A. is associated with both cirrhosis and hepatoma in Uganda (Maynard et al., 1970; Vogel et al., 1970). However, well-controlled follow-up studies of patients with hepatitis have failed to show an increased risk of cirrhosis (Nefzger and Chalmers, 1963; Beebe and Simon, 1970), and several reports from the United States and United Kingdom disclosed little association between H.A.A. and cirrhosis or hepatoma (Fox et al., 1969; Wright et al., 1969). The apparent dilemma would be resolved if H.A.A.-associated hepatitis, which is a common form of hepatitis in Accra and probably elsewhere in Africa, is associated with cirrhosis and hepatoma, whereas short-incubation hepatitis, the commonest type of hepatitis in North America and Europe, has no relation to cirrhosis or hepatoma.

Men have a much higher incidence of cirrhosis and hepatoma than women, and a striking feature in our series was the predominance of men among patients with persistent jaundice. Bulkley et al. (1970) reported that H.A.A. hepatitis patients with prolonged jaundice are predominantly men, whereas non-H.A.A. hepatitis patients with prolonged jaundice are predominantly women and often have a positive lupus erythematosus test.

Another unusual finding in our series was the distinctive histopathology associated with the hepatitis. Since this had also been described in many of the cases in the massive waterborne short-incubation hepatitis epidemic in Delhi in 1955 (Smetana, 1957; Viswanathan, 1957) the pattern might better be considered a manifestation of host factors rather than a marker of the infecting agent. Long-term follow-up of the Delhi patients failed to show a significant increase in chronic liver disease (Chuttani et al., 1966). A recent outbreak in Delhi, reminiscent of the 1955 epidemic, was investigated and all patients were negative for H.A.A. (Malaviya et al., 1971).

\section{References}

Barker, L. F., Peterson, M. R., and Murray, R. (1970). Vox Sanguinis, 19,

Beebe, G. W., and Simon, A. H. (1970). American fournal of Epidemiology, 92, 279 .

Blumberg, B. S. (1964). Bulletin of the New York Academy of Medicine, 40, 377.

Blumberg, B. S., Alter, H. J., and Visnich, S. (1965). Fournal of the American Medical Association, 191, 541.

Blumberg, B. S., Sutnick, A. I., and London, W. T. (1970). American Yournal of Medicine, 48, 1.

Bulkley, B. H., Heizen, W. D., Goldfinger, S. E., and Isselbacher, K. J. (1970). Lancet, 2, 1323

Chuttani, H. K., Sidhu, A. S., Wig, K. L., Gupta, D. N., and Ramalingaswami, V. (1966). British Medical fournal, 2, 676.

Cossart, Y. E., and Vahrman, J. (1970). British Medical fournal, 1, 403.

Del Prete, S., et al. (1970). Lancet, 2, 579.

Fox, R. A., Niazi, S. P., and Sherlock, S. (1969). Lancet, 2, 609.

Giles, J. P., McCollum, R. W., Berndston, L. W., jun., and Krugman, S. (1969). New England fournal of Medicine, 281, 119.

Grob, P. J., and Jemelka, H. (1971). Lancet, 1, 206.

Grob, P. J., and Jemelka, H. (1971). Lancet, 1, 206. Association, 212, 1019 .

Krugman, S., Giles, J. P., and Hammond, J. (1967). Fournal of the American Medical Association, 200, 365.

Mabayoje, J. O. (1962). Paper read at Conference of Association of Physicians of West Africa, University College Hospital, Ibadan, Nigeria, November 1962. 
Malaviya, A. N., Sama, S. K., Ramachandran, K., Gandhi, P. C., and Tandon, B. N. (1971). American fournal of Tropical Medicine and Hygiene, 20, 502.

Maynard, E. P., Sadikali, F., Anthony, P. P., and Barker, L. F. (1970) Lancet, $2,1326$.

Mirick, G. A., and Shank, R. E. (1959). Transactions of the American Clinical and Climatological Association, 71, 176.

Morrow, R. H., jun., Smetana, H. F., Sai, F. T., and Edgcomb, J. H. (1968). Annals of Internal Medicine, 68, 1250.

Morrow, R. H., jun., Sai, F. T., Edgcomb, J. H., and Smetana, H. F. (1969). Transactions of the Royal Society of Tropical Medicine and Hygiene, 63, 755.

Mosley, J. W., Barker, L. F., Shulman, N. R., and Hatch, M. H. (1970). Nature, 225, 953.

Nefzger, M. D., and Chalmers, T. C. (1963). American fournal of Medicine, 35, 299.

Ogunlesi, T. O. (1962). Paper read at Conference of Association of Physicians of West Africa, University College Hospital, Ibadan, Nigeria, November 1962.
Payet, M., Camain, R., Pene, P., Moalainer, M., and Sankale, M. (1962). Paper read at Conference of Association of Physicians of West Africa, University College Hospital, Ibadan, Nigeria.

Prince, A. M. (1970). American fournal of Tropical Medicine and Hygiene, 19,872 . Ringentz, O., and Zetterberg, B. (1967). New England fournal of Medicine,
276, 540.

Shulman, N. R., and Barker, L. F. (1969). Science, 165, 304.

Shulman, N. R., Hirschman, R. J., and Barker, L. F. (1970). Annals of Internal Medicine, 72, 257.

Smetana, H. F. (1957). In Hepatitis Frontiers, Henry Ford Hospital International Symposium, ed. F. W. Hartman, G. A. Lo Grippo, J. G. national Symposium, ed. F. W. Hartman, G. A.

Viswanathan, R. (1957). In Hepatitis Frontiers, Henry Ford Hospital International Symposium, ed. F. W. Hartman, G. A. Lo Grippo, J. G. Mateer, and J. Barrow, p. 207. Boston, Little, Brown.

Vogel, C. L., Mody, N., Anthony, P. P., and Barker, L. F. (1970). Lancet, 2,621 .

Vyas, G. N., and Shulman, N. R. (1970). Science, 170, 332.

Wright, R., McCollum, R. W., and Klatskin, G. (1969). Lancet, 2, 117.

\title{
Effect of Hormonal Therapy on Plasma Testosterone Levels in Prostatic Carcinoma
}

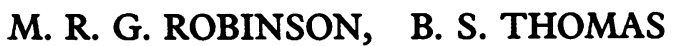

British Medical fournal, 1971, 4, 391-394

\section{Summary}

Plasma concentrations of testosterone were estimated in normal men, in patients before treatment for prostatic cancer, and in patients who had had various forms of endocrine treatment for prostatic carcinoma. There was no decline in plasma testosterone levels with age. Patients with non-metastatic disease had levels similar to those of normal controls, but in advanced metastatic disease the levels were low. After orchidectomy the plasma testosterone level fell to that found in normal women. In every patient stilboestrol in doses as small as $1 \mathrm{mg}$ three times a day suppressed plasma testosterone at first to negligible amounts, irrespective of the clinical response. Subsequently a small but significant rise in the concentration was always observed over a period of six months' oestrogen therapy. Pituitary ablation with yttrium-90 lowered the plasma testosterone concentration again to negligible amounts in patients who had been on stilboestrol. In advanced metastatic disease this was often associated with relief of pain. Preliminary studies with aminoglutethimide indicate that it can produce biochemical and clinical effects similar to those of pituitary ablation.

\section{Introduction}

Our purpose was to study the effect on plasma testosterone levels of the various forms of endocrine therapy for prostatic carcinoma. We therefore measured concentrations of plasma testosterone before and during treatment and compared them with those in normal men. The treatments included stilboestrol, orchidectomy, pituitary ablation, and "medical adrenalectomy"

Institute of Urology, London WC28 $8 \mathrm{JE}$

M. R. G. ROBINSON, F.R.C.S., Research Fellow

Department of Clinical Endocrinology, Imperial Cancer Research Fund, London WC2A 3PX

B. S. THOMAS, PH.D., M.I.BIOL., Senior Technical Officer with aminoglutethimide combined with oestrogen therapy. Surgical adrenalectomy was considered unsuitable for elderly patients with advanced disease.

The plasma testosterone was measured by the method of Thomas (1971). Concentrations of testosterone as low as $10 \mathrm{ng} / 100 \mathrm{ml}$ plasma can be measured by this test.

\section{Patients and Methods}

Forty-five patients with carcinoma of the prostate were studied before and during hormonal therapy, and 25 men without evidence of the disease and in good general health were used as controls.

The 45 patients had an examination of the prostate under general anaesthesia, cystoscopy, intravenous pyelography, chest $x$-ray examination, skeletal surveys by radiography and strontium-90 scintigraphy, and serum acid phosphatase measurements. In each case the diagnosis of prostatic carcinoma was confirmed by histological examination of biopsy specimens taken with a Vim-Silverman needle or by cytological examination of material aspirated by a Franzen needle (Williams et al., 1967). Because of the diurnal variation in the concentration of plasma testosterone (Saxena and Gandy, 1970), blood for testosterone assay was taken only between 9 and 11 a.m. Results from specimens taken on the day of admission to hospital or on the day of any surgical procedure were disregarded, since anxiety is often associated with a raised testosterone level.

\section{Results}

The patients with prostatic cancer were divided into those without metastases (age range 51-80 years, mean 69) and those with metastases (age range 52-78 years, mean 64). The plasma testosterone levels in the patients in each group are expressed as the mean of three assays made on three consecutive days. The age range of the men in the control group was 20-78 years, and in their case only single assays were made.

Fig. 1 relates plasma testosterone concentrations to age in the controls and in untreated cases of carcinoma of the prostate. Fig. 2 compares the testosterone levels in controls aged under 